\title{
Analysis of the Employee Stock Ownership Policy in State-controlled Mixed-ownership Enterprises
}

\author{
Wang Han ${ }^{1, *}$ Chen Qi $^{2}$ Gao Tong ${ }^{3}$ \\ ${ }^{1}$ State Grid Energy Research Institute Co.,Ltd., Beijing, 102209, China \\ ${ }^{2}$ State Grid Corporation of China, Beijing, 100031, China \\ ${ }^{3}$ State Grid Changchun Power Supply Company, Changchun, 130021, China \\ * Corresponding author's e-mail: wanghan@sgeri.sgcc.com.cn
}

\begin{abstract}
Employee stock ownership is the main way for state-controlled mixed-ownership enterprises to carry out medium and long-term incentives. The mixed-ownership corporate governance model provides convenient conditions for diversified shareholders to hold shares, and also lays a good foundation for the development of employee shareholding. The implementation of employee shareholding started earlier, and related policies have undergone multiple rounds of revision and improvement. This article sorts out the relevant policy context of employee stock ownership, and analyzes the current policy content to provide strong support for state-owned mixed-ownership enterprises to carry out employee stock ownership.
\end{abstract}

Keywords: Employee Stock ownership, Medium and Long-term Incentives, Policy Analysis

\section{INTRODUCTION}

The relevant policies on employee stock ownership in state-controlled mixed-ownership enterprises were issued much earlier than the relevant policies on equity incentives for state-controlled listed companies and equity and dividend incentives for state-owned technology enterprises. As early as the 1990s, employee shareholding was used as a means of directional stock raising by a company limited by shares, and its legal status had been determined. In the process of evolution, the policies related to employee shareholding in statecontrolled mixed-ownership enterprises have undergone several relatively large adjustments. Policies at different stages are quite different in terms of policy orientation, scope of application, and incentive objects. The nature, significance and main objectives of employee stock ownership have also undergone major changes.

\section{AN OVERVIEW OF RELEVANT POLICIES ON EMPLOYEE STOCK OWNERSHIP IN STATE-CONTROLLED MIXED-OWNERSHIP ENTERPRISES}

\subsection{Exploration Stage (1992 2002)}

In the $1980 \mathrm{~s}$, some state-owned enterprises began to issue stocks to internal employees to raise funds to expand production. In order to further standardize such stock raising behaviors of enterprises, relevant state ministries and commissions have issued a series of policies at this stage, which respectively set detailed regulations on the requirements and conditions of internal employee shareholding in private equity and social equity joint stock companies.[1]

As early as 1992, the National Economic System Reform Commission had specified the shareholding ratio of internal employees, transfer restrictions, and the shareholders' rights and interests of employees holding shares in the "Regulatory Opinions on Limited Companies". In addition, raising internal employees is one of the main sources of the company's share raising. For the first time, the compliance of employee shareholding has been clarified at the policy level, so that 
employee shareholding has become rule-based and evidence-based.

With the gradual promotion of internal employee shareholding, irregularities exposed in the implementation process have gradually increased. Relevant national ministries and commissions successively issued the "Emergency Notice of the General Office of the State Council on Forwarding the Opinions of the National Economic Reform Commission and Other Departments on Immediately Stopping the Issuance of Internal Employee Shares Irregular Practices", "Regulations on the Administration of Employee Stock Ownership", "the Notice on Clearing up the Irregular Practices of Internal Employee Stock Ownership of Privately Offered Limited Company" and other documents, which emphasize and refine the relevant requirements and restrictions on internal employee shareholding to promote the healthy development of employee shareholding.

In June 1994, the State Commission for Economic Restructuring issued the "Notice on Immediately Suspension of Approval of Privately Offered Limited Company and Reiteration of the Stop of Approval and Issuance of Internal Employee Shares".[2] The document requires enterprises to "suspend the approval and issuance of internal employee shares before the introduction of the new measures" in accordance with the "Notice of the State Council on Continued Strengthening of Macro-Control of Fixed Asset Investment". Since then, the implementation of employee shareholding has slowed down, and the national level has not issued a universal policy for internal employee shareholding in the next few years.

Until November 1998, the China Securities Regulatory Commission issued the "Notice on Stop Issuing Internal Employee Shares." The document clearly stipulates that "a joint stock limited company shall no longer issue company employee shares for public offerings." Since then, employee shareholding has entered a longer period of adjustment and adaptation, and no large-scale promotion has been carried out for a long time.

Generally speaking, although the internal employee shareholding at this stage is very similar in form to the current state-controlled mixed-ownership employee shareholding mechanism, the connotations of the two are very different. The internal employee shareholding in this period was mainly from the level of share offering, through a relatively large-scale and more inclusive internal share offering, so that employees could have shareholder power and enjoy corresponding benefits. Therefore, in contrast, employee stock ownership in this period is closer to welfare, rather than a medium- and long-term incentive for the company's core employees.

\subsection{Adjustment Stage (2003 2012)}

Since the China Securities Regulatory Commission stopped the public offering of employee shares by joint stock companies in 1998, employee shareholding has been silent for a long time. Among them, the units that have implemented internal employee shareholding still pay dividends to employees in accordance with the original method but have not expanded the scope of shareholding. With the continuous advancement of the restructuring of state-owned enterprises, employee shareholding, as an important way to transform enterprise ownership, has once again entered the public's field of vision and has become an important means and way to promote the reform of enterprise shareholding.

In November 2003, the General Office of the State Council issued the "Opinions on Regulating the Restructuring of State-owned Enterprises", requiring that management buyouts in the restructuring of state-owned enterprises must strictly comply with relevant state regulations and perform approval procedures in accordance with relevant regulations. The "Notice on Further Regulating the Restructuring of State-owned Large and Medium-Sized Enterprises" and the "Implementation Opinions on Further Regulating the Restructuring of State-owned Enterprises" issued subsequently have further clarified the relevant requirements for management buyouts.[3]

In September 2008, the State-owned Assets Supervision and Administration Commission of the State Council promulgated the "Opinions on Regulating Employee Stock Ownership and Investment in StateOwned Enterprises", regarding the participation of stateowned enterprise employees in the restructuring of stateowned small and medium-sized enterprises, the restructuring of auxiliary businesses of state-owned large and medium-sized enterprises, and the restructuring of scientific research institutes by scientific and technological backbones. The specification. The document requires strict control of the scope of employee shareholding enterprises, standardization of the form of employee shareholding, clarification of requirements for employee share transfers, and standardization of the source of funds for shareholding.

On the whole, employee shareholding at this stage has begun to be closely related to the reform of state-owned enterprises, and the scope of shareholding is wider and more inclusive. Relevant policies are also mainly to clarify and regulate related matters involving management buyouts and employee stock ownership during the restructuring of state-owned enterprises. In general, employee stock ownership in this period was more of a means to promote the restructuring of stateowned enterprises, rather than an incentive in a pure sense. 


\subsection{Transition Stage (2013-present)}

In 2012, the 18th National Congress of the Communist Party of China made major arrangements for deepening the reform of state-owned enterprises, and the curtain of reform was officially opened. As an important participant in state-controlled mixed-ownership enterprises, employees have increasingly respected and affirmed their shareholding status and rights, and the mid- to long-term incentive effect of employee shareholding on core employees has also received increasing attention.

In 2013, the Third Plenary Session of the Eighteenth Central Committee of the Communist Party of China passed the "Decisions of the Central Committee of the Communist Party of China on Several Major Issues of Comprehensively Deepening Reform." It clearly stipulates that "a mixed ownership economy is allowed to implement enterprise employee shareholding, forming a community of interests of capital owners and workers." This is the first time that employee stock ownership has been proposed in a national policy to enable enterprises and employees to form a community of interests, emphasizing the incentive properties of employee stock ownership.

In 2014, the State Council promulgated the "Several Opinions of the State Council on Further Promoting the Healthy Development of the Capital Market", which clearly stated that it is necessary to "improve the equity incentive system for listed companies and allow listed companies to carry out employee stock ownership plans in various forms in accordance with regulations." Subsequently, the "Guiding Opinions on the Pilot Implementation of Employee Stock Ownership Plans by Listed Companies" and the "Drafting Instructions on the Guiding Opinions on the Pilot Implementation of Employee Stock Ownership Plans by Listed Companies" were issued one after another. The document stipulates the principles, main contents and implementation procedures of listed companies' employee stock ownership plans.[4]

In August 2016, the State-owned Assets Supervision and Administration Commission of the State Council, the Ministry of Finance, and the China Securities Regulatory Commission jointly issued the "Opinions on the Pilot Employee Stock Ownership of State-controlled Mixed Ownership Enterprises". This is the first time that the national policy level has separately clarified the employee shareholding of state-controlled mixed ownership enterprises. Specifications. The document stipulates the principles for carrying out the pilot program of employee shareholding, the conditions of pilot enterprises, employee shareholding and equity management, and the organization and implementation of pilot work. Subsequently, the National Development and Reform Commission and the State-owned Assets
Supervision and Administration Commission of the State Council successively issued the "Opinions on Several Policies on Deepening the Pilot Mixed Ownership Reform" and the "Operational Guidelines for the Mixed Ownership Reform of Central Enterprises". The documents provide further explanations and summaries of the relevant policies on employee shareholding in state-controlled mixed-ownership enterprises.

On the whole, the employee stock ownership policy at this stage has been continuously deepened and improved along with the deepening of the reform of stateowned assets and state-owned enterprises. From the point of view of the principle of piloting employee shareholding in the policy, employee shareholding has completely transformed from an inclusive employee welfare or state-owned enterprise restructuring method to an important incentive method for key core talents of enterprises. The management and implementation of employee stock ownership is also more standardized. However, due to the short time for the introduction of relevant policies, the number of companies participating in the pilot program is still relatively small, and there is still room for further improvement of relevant policies.

\section{CURRENT POLICY RELATED REQUIREMENTS}

\subsection{Implementation Principle}

In the "Opinions on the Pilot Program of Employee Stock Ownership in State-controlled Mixed Ownership Enterprises," the implementation principles of employee stock ownership are clearly defined as "lawful compliance, openness and transparency, incremental introduction, interest binding, job-based stock determination, dynamic adjustment, strict Control the scope and strengthen supervision". In the "Operational Guidelines for Mixed Ownership Reform of Central Enterprises" issued in 2019, this principle was once again cited and emphasized. In the "Opinions on Several Policies for Deepening the Pilot Reform of Mixed Ownership" issued in 2018, this principle has been finetuned, and it has been revised to "adhere to laws and regulations, open and transparent, based on increments, immovable stocks, and same shares. Same price, cash share, share fixed by post, dynamic adjustment".[5]

By comparing before and after, it is not difficult to see that in the document "Opinions on Deepening Several Policies for the Pilot Program of Mixed Ownership Reform", the National Development and Reform Commission is more active in promoting employee shareholding. It no longer emphasizes the scope of implementation and supervision and control, but focuses on the price and method for employees to invest in shares, that is, "same stock at the same price, cash for shares." The other two documents emphasized the implementation direction and conditions of employee 
stock ownership. In the direction of implementation, the four words "benefit binding" indicate that the main purpose of employee stock ownership is to realize the benefit sharing between employees and corporate shareholders, rather than management equity purchases. Therefore, it is necessary to pay attention to the direction of plan formulation and the choice of incentive objects. In terms of the scope of implementation, the emphasis on "strictly controlling the scope and strengthening supervision" shows that the threshold for implementing employee stock ownership will not be lowered within a period of time. A series of problems and irregular practices in the practice of employee stock ownership will also be further regulated and corrected.

\subsection{Source of Equity and Scope of Applicable Companies}

In the principles of the three documents, it is emphasized that the source of employee stock ownership is "incremental introduction." The "Opinions on the Pilot Program of Employee Stock Ownership by Statecontrolled Mixed Ownership Enterprises" clearly stated that "employee shareholding will mainly be carried out by means of capital increase and share expansion, and new capital contributions."

According to the "Opinions on the Pilot Program of Employee Stock Ownership by State-controlled Mixed Ownership Enterprises", the pilot companies shall meet the following requirements. (1) Commercial enterprises whose main business is in fully competitive industries and fields. (2) The equity structure is reasonable, and the shares held by shareholders of non-public capital should reach a certain proportion. (3) The company has a sound corporate governance structure, and establishes a marketoriented labor and personnel distribution system and a performance evaluation system (4) More than $90 \%$ of operating income and profits come from the external market of the enterprise group. In addition, the selection of objects also reflects the priority orientation of technological enterprises.

\subsection{Shareholding Ratio and Holding Method}

Relevant documents clearly require that, in principle, the total shareholding of employees shall not exceed $30 \%$ of the company's total share capital. In principle, the shareholding ratio of a single employee shall not be higher than $1 \%$ of the company's total share capital. And after the implementation of employee shareholding, the shareholding ratio of state-owned shareholders shall not be less than $34 \%$ of the company's total share capital.

The "Opinions on the Pilot Program of Employee Stock Ownership in State-controlled Mixed Ownership Enterprises" stipulates that employees who hold shares can directly hold shares in their own names, or they can hold equity through shareholding platforms such as corporate enterprises, partnership enterprises, and asset management plans. Those holding shares through an asset management plan shall not use leveraged financing.

\section{CONCLUSION}

Compared with other medium and long-term incentive methods of state-owned enterprises, although employee shareholding has an earlier start-up time and a longer implementation time, it has undergone several major changes in the process. From the perspective of policy orientation, the current Party Central Committee still has reservations about the shareholding of employees of state-controlled mixed-ownership enterprises, and it is still in pilot projects. The scope of the company, the method of holding shares, the incentive objects, and the proportion of shares held by employees are all strictly controlled.

\section{ACKNOWLEDGMENT}

This project is supported by the State Grid Corporation of China Technology Project "Research on Talent Supply and Demand Analysis Model and Supply Strategy Research Adapting to Company Strategy" (SGSC0000KXJS2000095).

\section{REFERENCES}

[1] Li, Y., Research on Establishing Mid- and Longterm Incentive Mechanism for State-owned Enterprises, in: Modern Commerce, vol.22, Beijing, China, 2017, pp. 129-130. DOI: 10.14097/j.cnki.5392/2017.22.048

[2] Jin, Z., Research on Mid- and Long-term Incentive Methods of Conventional Enterprises, in: Modern Economic Information, vol.12, Beijing, China, 2017, PP.70. DOI: 10.3969/j.issn.1001-828X.2017.18.050

[3] Deng, L., Discussion on Mid- and Long-term Incentives for Enterprises, in: Human Resources Management, vol.10, Beijing, China, 2013, pp.173. DOI: $10.3969 /$ j.issn.1673-8209.2013.10.092

[4] Ran. Q., Research on the Employee Stock Ownership in the Reform of State-owned Enterprise Mixed Ownership, in: Cooperative Economics and Technology, vol.1, Beijing, China, 2019, pp. 130131. DOI: 10.3969/j.issn.1672-190X.2019.24.055.

[5] Song, H., Employee Stock Ownership and Corporate Performance, in: Economist, vol.7, 2020, pp. 27. DOI: 10.3969/j.issn.1004-4914.2020.07.145. 